\title{
KENDALI OPTIMAL MODEL LCS PADA POPULASI TANAMAN PADI SAWAH DARI SERANGAN HAMA TIKUS SAWAH DAN WBC MENGGUNAKAN PRINSIP MINIMUM PONTRYAGIN
}

\author{
G. Triwidodo스. R. Ratianingsih², dan N. Nacong ${ }^{3}$ \\ 1,2,3Program Studi Matematika Jurusan Matematika FMIPA Universitas Tadulako \\ Jalan Soekarno-Hatta Km. 09 Tondo, Palu 94118, Indonesia. \\ 1gatottriwidodo12@gmail.com, 2ratianingsih@yahoo.com,3nasrianacong@gmail.com
}

\begin{abstract}
Rice field plants (Oryza sativa) is one of the main food crop that very essential for common poeple. On the other hand, rice become as the main commodity of the common poeple. According to Badan Pusat Statistik (BPS) data, the consumption of it in 2011 reached $139 \mathrm{~kg}$ of capita ${ }^{-1}$ year $^{-1}$ due to 237 million of Indonesian resident. The cultivation of rice field production obstacle is the pest attack. The able prime pest that caused the rice production damage is field mouse pest (Rattus argintiventer) and rice stem pest (Nilaparvata Lugens). Both types have a very high reproduction rate. This research studies mathematically the damage of rice field plants population control at vegetative phase. That designed to minimize the number of vegetative rice population phase. A logistic Competing Species model is built to describe the interaction between both the pest at the vegetative phase rice growth. The Pontryagin minimum principles is used to determine the optimal control solution. The solution is solved from the state and co-state equation that stationery evaluated using the indexed performance $\operatorname{minJ}_{t_{0}}^{t_{f}}\left[\frac{1}{2}\left(u_{1}^{2}+u_{2}^{2}\right)-P v\right] d t$
\end{abstract} with optimal control $u_{1}^{*}=\lambda_{2} P v T$ and $u_{2}^{*}=\lambda_{2} P v W$. The research result of indicate that the optimal control just optimalize the vegetative rice phase damage while the pest is not optimalized yet.

Keyword : Stability, Jacoby Matrix, Eigen Value, Pontryagin Minimum, Oryza Sativa, Rattus Argintivente,

\section{Nilaparvata Lugens}

\section{ABSTRAK}

Tanaman padi sawah (Oryza sativa) merupakan salah satu tanaman pangan yang menjadi makanan pokok sebagian manusia. Di Indonesia padi merupakan komoditi utama penyokong masyarakat. Menurut data Badan Pusat Statistik (BPS) tahun 2011, konsumsi beras pada tahun 2011 mencapai $139 \mathrm{~kg} \mathrm{kapita}^{-1}$ tahun $^{-1}$ dengan jumlah penduduk 237 juta jiwa. Hambatan yang ditemui dalam budidaya tanaman padi, diantaranya adalah serangan hama. Hama utama yang dapat menyebabkan kerusakan padi hingga puso adalah hama tikus sawah (Rattus argintiventer) dan wereng batang coklat (Nilaparvata lugens). Kedua jenis hama tersebut memiliki laju perkembangbiakan yang sangat tinggi. Penelitian ini mengkaji secara matematis pengendalian kerusakan populasi tanaman padi sawah pada fase vegetatif. Pengendalian tersebut dirancang untuk meminimumkan banyaknya populasi padi fase vegetatif yang terserang hama. Model Logistic Competing Species (LCS) dibangun untuk 
menggambarkan interaksi antara kedua hama tersebut pada pertumbuhan padi fase vegetatif. Prinsip minimum Pontryagin digunakan untuk menentukan kendali optimal yang diperoleh dari solusi kendali optimal. Solusi tersebut merupakan penyelesaian dari persamaan state dan co-state yang dievaluasi pada kondisi stasioner. Dalam penelitian ini diperoleh Indeks Performance ${ }_{\operatorname{minJ}}=\int_{t_{0}}^{t_{f}}\left[\frac{1}{2}\left(u_{1}^{2}+u_{2}^{2}\right)-P v\right] d t$ dengan kendali optimal $u_{1}^{*}=\lambda_{2} P v T$ dan $u_{2}^{*}=\lambda_{2} P v W$. Hasil penelitian menunjukkan bahwa kendali optimal yang dibangun hanya optimal untuk mengendalikan tingkat kerusakan padi fase vegetatif, sedangkan pengendalian populasi hama tikus dan wereng batang coklat yang dibangun belum optimal. Hal ini disebabkan desain kendali optimal yang hanya meminimumkan jumlah kerusakan populasi tanaman padi fase vegetatif.

Kata Kunci : Kestabilan, matiks Jacobi, Nilai eigen, Minimum Pontryagin, Oryza satifa, Rattus argintiventer, Nilaparvata lugens

\section{PENDAHULUAN}

Indonesia sebagai negara agraris memiliki lahan pertanian yang sangat luas dan subur. Hal ini menjadikan sebagian besar penduduk Indonesia berprofesi sebagai petani, salah satunya adalah petani padi. Padi merupakan salah satu tanaman pangan yang memegang peranan penting dalam kehidupan manusia. Padi merupakan sumber karbohidrat yang tinggi selain jagung dan gandum. Sebagian masyarakat Indonesia mengonsumsi nasi yang berasal dari beras yang merupakan produk dari tanaman padi. Padi merupakan varietas tanaman yang disepanjang masa pertumbuhannya membutuhkan banyak air.

Pada tahun 1970-an terjadi wabah hama wereng coklat. Ribuan persilangan kemudian dirancang untuk menghasilkan kultivar dengan potensi hasil tinggi dantahan terhadap berbagai hama dan penyakit padi. Program-program tersebut telah dapat meningkatkan produksi padi di Indonesia, puncaknya pada tahun 1984 target swasembada beras tercapai (Rismunandar, 1993). Sehingga pemerintah Indonesia meraih penghargaan dari PBB (FAO). Prestasi ini tidak dapat dilanjutkan dan baru mulai kembali pulih pada tahun 2007.

Prestasi Indonesia dalam swasembada beras menurun dikarenakan banyaknya kendala yang dihadapi oleh petani saat melakukan budidaya tanaman padi sawah. Salah satu faktor yang dapat menyebabkan kegagalan panen adalah adanya serangan hama dan penyakit. Hama utama yang sangat merugikan petani diantaranya adalah Hama Tikus dan Hama Wereng Batang Coklat (WBC).

Tikus merupakan salah satu hama utama di Indonesia yang menimbulkan kerugian besar. Gagal panen akibat serangan hama tikus sawah di Indonesia diperkirakan mencapai 200.000-300.000 ton per tahun (Harahap, I.S dan Thahjono, B., 1988). Beberapa cara pengendalian hama tikus telah dilakukan oleh para petani, namun dalam pelaksaan di lapangan pengendalian-pengendalian yang dilakukan masih belum mampu untuk menekan laju pertumbuhan hama tikus, sehingga masih terjadi kerusakan tanaman padi yang menyebabkan gagal panen. 
Hama wereng coklat (WBC) telah populer dikalangan petani sejak tahun 1970-an. WBC merupakan hama global karena tidak hanya menyerang tanaman padi di Indonesia, tetapi juga menyerang tanaman padi di Cina, Thailand, Vietnam, India, Bangladesh, Malaysia, Jepang dan Korea (Baehaki, 2011). Sejarah serangan WBC terbesar di Indonesia terjadi pada kurun waktu 1970-1980 yang mencapai 2,5 juta ha. Kerusakan akibat serangan hama WBC ini cukup luas dan hampir terjadi pada setiap musim tanam. Wereng coklat secara langsung akan menghisap cairan sel tanaman padi sehingga tanaman menjadi kering dan akhirnya mati.

Hama tikus dan hama WBC merupakan faktor yang sangat penting untuk mendapatkan hasil panen yang optimal. Kendali terhadap hama perlu dilakukan. Salah satu syarat keberhasilan usaha pengendalian adalah dengan meminimalisir penyerangan hama tanaman padi di sepanjang masa pertumbuhannya. Metode kendali yang tepat akan mendapatkan hasil panen yang maksimal.

\section{METODE PENELITIAN}

Metode penelitian ini menggunakan penelusuran literatur dengan menelaah artikel dan jurnal ilmiah terkait model $L C S$, tanaman padi, ekologi tikus sawah dan wereng batang coklat. Kemudian membangun model matematika LCS, menganalisa kestabilan model tersebut menggunakan Matriks Jacobi serta menyelesaikan kendali optimal model LCS dengan menggunakan metoda Minimum Pontryagin.

\section{Hasil dan Pembahasan}

Penelitian ini merupakan tinjauan matematis terhadap populasi tanaman padi sawah yang direpresentasikan ke dalam model matematika. Model matematika dibangun berdasarkan asumsiasumsi dan kemudian dianalisis untuk mengetahui bagaimana pertumbuhan populasi tanaman padi sawah seiring dengan berjalannya waktu.

\subsection{Kontruksi Model Matematika}

Untuk mendapatkan kontruksi model, perlu digambarkan diagram kompartemen pertumbuhan populasi tanaman padi yang mendapatkan serangan dari hama tikus dan hama wereng batang coklat, diagram kompartemen tersebut disajikan dalam Gambar 1. 


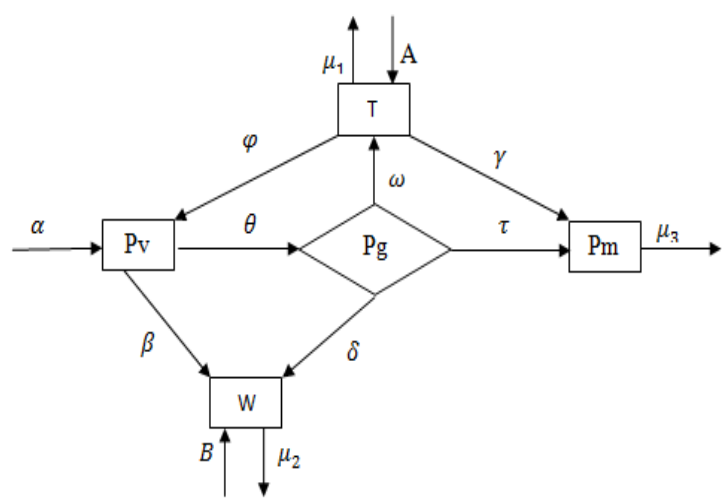

Gambar 1: Diagram Kompartemen Model LCS

Diagram kompartemen pada gambar satu menunjukan pertumbuhan populasi tanaman padi sawah yang terserang hama tikus sawah dan wereng batang coklat. Dari diagram tersebut dibangun model matematika yang dinyatakan dalam sistem persamaan diferensial (SPD) sebagai berikut :

$\frac{d T}{d t}=A-\mu_{1} T$

$\frac{d P v}{d t}=\alpha P v\left(1-\frac{P v}{K}\right)-\varphi P v T-\theta P v-\beta P v W$

$\frac{d P g}{d t}=\theta P v-\omega P g T-\tau P g-\delta P g W$

$\frac{d P m}{d t}=\tau P g-\gamma P m T-\mu_{3} P m$

$\frac{d W}{d t}=B-\mu_{2} W$

\section{Keterangan :}

$T \quad$ : Populasi hama tikus

$P v \quad: \quad$ Populasi tanaman padi fase vegetatif

$P g$ : Populasi tanaman padi fase generatif

$\mathrm{Pm} \quad$ : Populasi tanaman padi matang

$W \quad$ : Populasi hama WBC

A : Laju kelahiran tikus secara alami

$\alpha \quad$ : Laju pertumbuhan tanaman padi fase vegetatif secara alami

$B \quad$ : Laju kelahiran hama WBC alami

$\mu_{1} \quad$ : Laju kematian hama tikus secara alami

$\mu_{2} \quad$ : Laju kematian hama WBC secara alami

$\mu_{3} \quad$ : Laju kematian tanaman padi matang secara alami 
$\varphi \quad$ : Laju kerusakan tanaman padi fase vegetatif akibat serangan hama tikus

$\omega \quad$ : Laju kerusakan tanaman padi fase generatif akibat serangan hama tikus

$\gamma \quad$ : Laju kerusakan tanaman padi matang akibat serangan hama tikus

$\theta \quad: \quad$ Laju pertumbuhan tanaman padi fase vegetatif ke fase generatif

$\tau \quad: \quad$ Laju pertumbuhan tanaman padi fase generatif ke fase matang

$\beta \quad$ : Laju kerusakan tanaman padi fase vegetatif akibat serangan hama WBC

$\delta \quad: \quad$ Laju kerusakan tanaman padi fase generatif akibat serangan hama WBC

$\rho \quad: \quad$ Laju kerusakan tanaman padi matang akibat serangan hama WBC

K : Carrying Capacity

Titik kritis model yang dibangun diperoleh dengan meninjau SPD pada keadaan stagnan , sehingga diperoleh titik kritis tak nol sebagai berikut:

$$
\begin{aligned}
& T=\frac{A}{\mu_{1}} \\
& P v=\frac{K\left(\alpha \mu_{1} \mu_{2}-\mu_{2} \varphi A-\theta \mu_{1} \mu_{2}-\mu_{1} B \beta\right)}{\alpha \mu_{1} \mu_{2}} \\
& P g=\frac{\theta\left(K\left(\alpha \mu_{1} \mu_{2}-\mu_{2} \varphi A-\theta \mu_{1} \mu_{2}-\mu_{1} B \beta\right)\right)}{\alpha\left(\omega A \mu_{2}-\tau \mu_{1} \mu_{2}-\delta B \mu_{1}\right)} \\
& P m=\frac{\tau \mu_{1} \theta\left(K\left(\propto \alpha \mu_{2}-\mu_{2} \varphi A-\theta \mu_{1} \mu_{2}-\mu_{1} B \beta\right)\right)}{\alpha\left(\omega A \mu_{2}-\tau \mu_{1} \mu_{2}-\delta B \mu_{1}\right) \gamma A-\mu_{3} \mu_{1}} \\
& W=\frac{B}{\mu_{2}}
\end{aligned}
$$

Titik kritis menggambarkan banyaknya populasi pada tiap fase pertumbuhan padi, populasi hama tikus sawah dan WBC dalam kondisi stagnan. Kestabilan dari titik kritis tersebut ditentukan berdasarkan nilai eigen yang diperoleh dengan memperhatikan koefisien dari persamaan karakteristik melalui bagian real dari akar-akar karateristik yang dihitung di titik tersebut.

Hasil analisa kestabilan menunjukkan bahwa sistem tidak stabil di titik kritis endemik. Hal ini disebabkan nilai eigen ke dua pada titik kritis endemik bernilai positif.

\subsection{Penyelesaian Kendali}

Untuk mengatasi kerusakan populasi tanaman padi pada semua fase dilakukan pengontrolan dengan memberikan rodentisida pada makanan hama tikus dan dengan melakukan penyemprotan insektisida pada tanaman padi untuk mengatasi hama WBC. Hal tersebut merupakan upaya pemberantasan tikus sawah dan WBC secara kimia. Secara matematis masalah pengendalian kerusakan padi fase vegetatif direpresentasikan melalui parameter $u_{1}$ sebagai tingkat pemberian rodentisida pada hama tikus dan $u_{2}$ sebagai tingkat penyemprotan hama WBC. 
Pengendalian kerusakan populasi tanaman padi sawah dilakukan dengan pemberian rodentisida dan penyemprotan insektisida. Secara matematis hal ini dilakukan dengan menempatkan parameter kontrol $u_{1}$ dan $u_{2}$ pada persamaan.

Pada penyelesaian kendali optimal ini dibangun suatu Indeks Performance model LCS dengan tujuan meminimalkan banyaknya populasi padi fase vegetatif yang terserang hama tikus dan WBC. Indeks Performance untuk mengontrol kerusakan populasi padi fase vegetatif adalah sebagai berikut :

$$
\min \mathrm{J}=\int_{t_{0}}^{t_{f}}\left[\frac{1}{2}\left(u_{1}^{2}+u_{2}^{2}\right)-P v\right] d t
$$

Untuk meminimumkannya, metode Minimum Pontryagin menyatakan penentuan fungsi Hamiltonian sebagai berikut :

$$
\begin{aligned}
& H=H\left(x, u_{1}, u_{2}, \lambda, t\right) \\
& \quad=V\left(x, u_{1}, u_{2}, t\right)+\lambda f\left(x,, u_{1}, u_{2}, t\right) \\
& H=\frac{1}{2}\left(u_{1}^{2}+u_{2}^{2}\right)-P v+\lambda_{1} A-\lambda_{1} \mu_{1} T+\lambda_{2} \alpha P v\left(1-\frac{P v}{K}\right)-\lambda_{2} u_{1} P v T-\lambda_{2} \theta P v-\lambda_{2} u_{2} P v W \\
& +\lambda_{3} \theta P v-\lambda_{3} \omega P g T-\lambda_{3} \tau P g-\lambda_{3} \delta P g W+\lambda_{4} \tau P g-\lambda_{4} \gamma P m T-\lambda_{4} \mu_{3} P m+\lambda_{5} B-\lambda_{5} \mu_{2} W
\end{aligned}
$$

Berdasarkan Prinsip Minimum Pontryagin, diperoleh solusi dari fungsi Hamilton berupa dosis pestisida yang optimal jika berlaku persamaan state, costate dan kondisi stasioner.

Penyelesaian kendali optimal dengan parameter $u_{1}$ dan $u_{1}$ diperoleh melalui persamaan state, co-state dan kondisi stasioner sebagai berikut :

a. Persamaan State

$$
\begin{aligned}
& T^{\&}=\frac{\partial H}{\partial \lambda_{1}}=A-\mu_{1} T \\
& \& \\
& P v=\alpha P v-\left(1-\frac{P v}{K}\right)-u_{1} P v T-\theta P v-u_{2} P v W \\
& \& \\
& P g=\theta P v-\omega P g T-\tau P g-\delta P g W \\
& \& \\
& P m=\tau P g-\gamma P m T-\mu_{3} P m \\
& W=B-\mu_{2} W
\end{aligned}
$$

b. Persamaan Co-State

$$
\begin{aligned}
\lambda_{1} & =-\frac{\partial H}{\partial T}=-\left(\lambda_{1} \mu_{1}+\lambda_{2} \mu_{1} P v+\lambda_{3} \omega P g+\lambda_{4} \gamma P m\right) \\
\lambda_{2} & =-\frac{\partial H}{\partial P v}=-\left(1+\frac{2 \lambda_{2} \alpha P v}{K}+\lambda_{2} u_{1} T+\lambda_{2} \theta+\lambda_{2} u_{2} W-\lambda_{3} \theta-\lambda_{2} \alpha\right) \\
\text { a. } \quad \lambda_{3} & =-\frac{\partial H}{\partial P g}=-\left(\lambda_{3} \omega T+\lambda_{3} \tau+\lambda_{3} \delta W-\lambda_{4} \tau\right) \\
\lambda_{4} & =-\frac{\partial H}{\partial P m}=-\left(\lambda_{4} \gamma T+\lambda_{4} \mu_{3}\right) \\
\lambda_{5} & =-\frac{\partial H}{\partial W}=-\left(\lambda_{2} u_{2}+\lambda_{3} P g+\lambda_{5} \mu_{2}\right)
\end{aligned}
$$


c. Kondisi Stasioner

$$
\begin{aligned}
& \frac{\partial H}{\partial u_{1}}=0 \\
& u_{1}-\lambda_{2} P v T=0 \\
& u_{1}^{*}=\lambda_{2} P v T
\end{aligned}
$$

dan

$\frac{\partial H}{\partial u_{2}}=0$

$u_{2}-\lambda_{2} P v W=0$

$u_{2}^{*}=\lambda_{2} P v W$

Kurva pertumbuhan model LCS digambarkan untuk kondisi awal hama Tikus (T) sebanyak 26 ekor, hama WBC (W) sebanyak 17 ekor, padi fase vegetatif (Pv) sebanyak 250 rumpun, padi fase genaratif $(\mathrm{Pg})$ sebanyak 240 rumpun dan paid matang $(\mathrm{Pm})$ sebanyak 230 rumpun. Pertumbuhan tiap kurva digambarkan untuk dua keadaan, yaitu tanpa kendali dan dengan kendali optimal.

Nilai-nilai parameter yang digunakan dalam menggambarkan kurva pertumbuhan

\begin{tabular}{|c|c|c|c|}
\hline Parameter & Deskripsi & Nilai & $\begin{array}{c}\text { Sumber } \\
\text { (Referensi) }\end{array}$ \\
\hline$A$ & Tingkat kelahiran tikus secara alami & 0,016 & Asumsi \\
\hline$\alpha$ & $\begin{array}{l}\text { Tingkat pertumbuhan tanaman padi fase } \\
\text { yegetatif secara alami }\end{array}$ & 0.25 & Fita Anggraini \\
\hline$B$ & Tingkat kelahiran hama WBC alami & 0.05 & $\begin{array}{l}\text { Yoherwandi, } \\
\text { Refinaldon, Ayu } \\
\text { Rahmadan }\end{array}$ \\
\hline$\mu_{1}$ & Laju kematian hama tikus secara alami & 0,0006 & $\frac{1}{\text { life time }}$ \\
\hline$\mu_{2}$ & Laju kematian hama WBC secara alami & 0,041 & $\frac{1}{\text { life time }}$ \\
\hline$\mu_{3}$ & $\begin{array}{l}\text { Laju kematian tanaman padi matang } \\
\text { secara alami }\end{array}$ & 0,0083 & $\frac{1}{\text { life time }}$ \\
\hline$\varphi$ & $\begin{array}{l}\text { Laju kerusakan tanaman padi fase } \\
\text { yegetatif akibat serangan hama tikus }\end{array}$ & 0,0325 & $\begin{array}{l}\text { Septiana } \\
\text { Angraeni }\end{array}$ \\
\hline$\omega$ & $\begin{array}{l}\text { Laju kerusakan tanaman padi fase } \\
\text { generatif akibat serangan hama tikus }\end{array}$ & 0,0196 & $\begin{array}{l}\text { Septiana } \\
\text { Angraeni }\end{array}$ \\
\hline$\gamma$ & $\begin{array}{l}\text { Laju kerusakan tanaman padi matang } \\
\text { akibat serangan hama tikus }\end{array}$ & 0,0197 & $\begin{array}{l}\text { Septiana } \\
\text { Angraeni }\end{array}$ \\
\hline$\theta$ & $\begin{array}{l}\text { Laju pertumbuhan tanaman padi fase } \\
\text { yegetatif ke fase generatif }\end{array}$ & 0,099 & Asumsi \\
\hline$\tau$ & $\begin{array}{l}\text { Laju pertumbuhan tanaman padi fase } \\
\text { generatif ke fase matang }\end{array}$ & 0,098 & Asumsi \\
\hline$\beta$ & $\begin{array}{l}\text { Laju kerusakan tanaman padi fase } \\
\text { yegetatif akibat serangan hama WBC }\end{array}$ & 0,0133 & $\begin{array}{l}\text { Solikhin dan } \\
\text { Pumomo }\end{array}$ \\
\hline$\delta$ & $\begin{array}{l}\text { Laju kerusakan tanaman padi fase } \\
\text { generatif akibat serangan hama WBC }\end{array}$ & 0,01 & $\begin{array}{l}\text { Solikhin dan } \\
\text { Pumomo }\end{array}$ \\
\hline$K$ & Carryng capasity & 10000 & Asumsi \\
\hline
\end{tabular}
tersebut dinyatakan dalam Tabel 1.

Tabel 1 : Nilai Parameter 
Perbandingan kruva pertumbuhan populasi hama tikus dengaan kendali dan tanpa kendali ditampilkan pada Gambar 2.

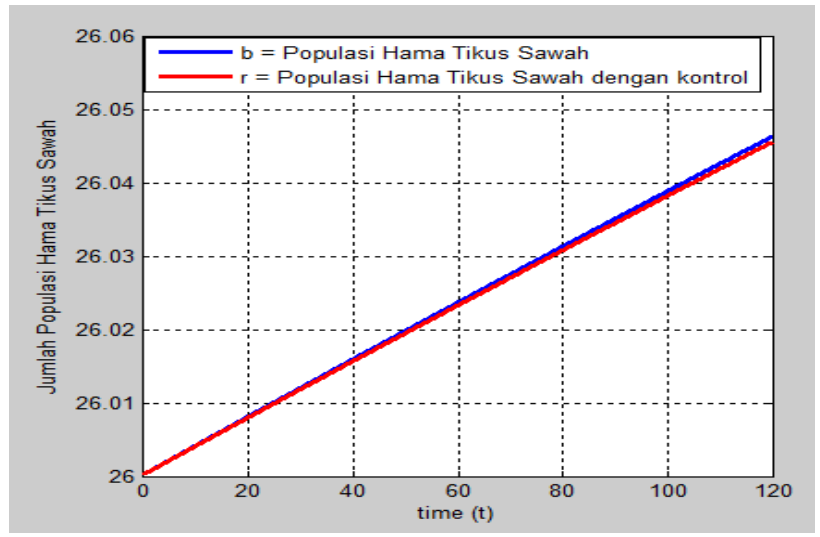

Gambar 2 : Populasi Hama Tikus Sawah tanpa dan dengan kendali

Gambar 2 memperlihatkan bahwa untuk populasi awal hama tikus sawah $T(0)=26$ ekor, populasi ini akan tetap berjumlah $\approx 26$ ekor pada hari ke-120 baik ketika dikendalikan maupun tanpa kendali.

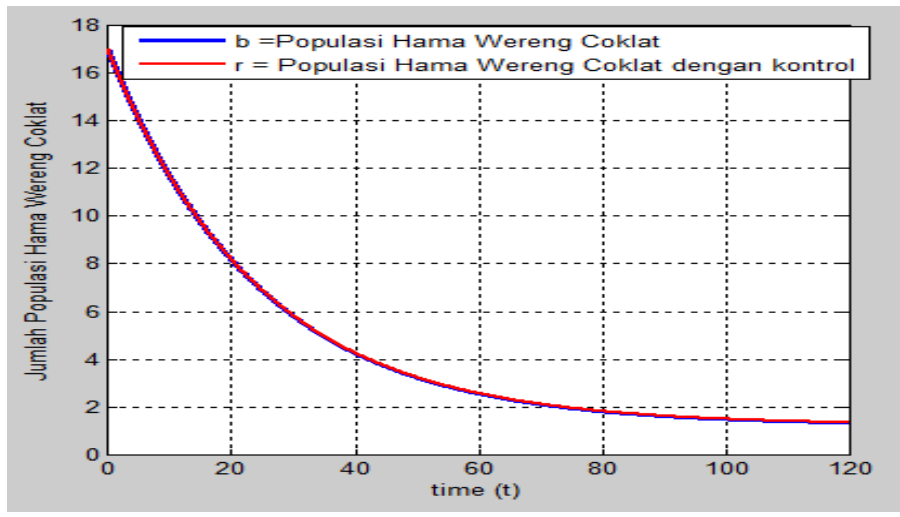

Gambar 3 : Populasi hama WBC dengan dan tanpa kendali

Gambar 3 memperlihatkan kurva populasi hama WBC yang diberikan sebanyak $W(0)=17$ ekor pada saat $t=0$, populasi ini mengalami penurunan hingga mendekati 1 ekor dalam waktu $t=120$. 


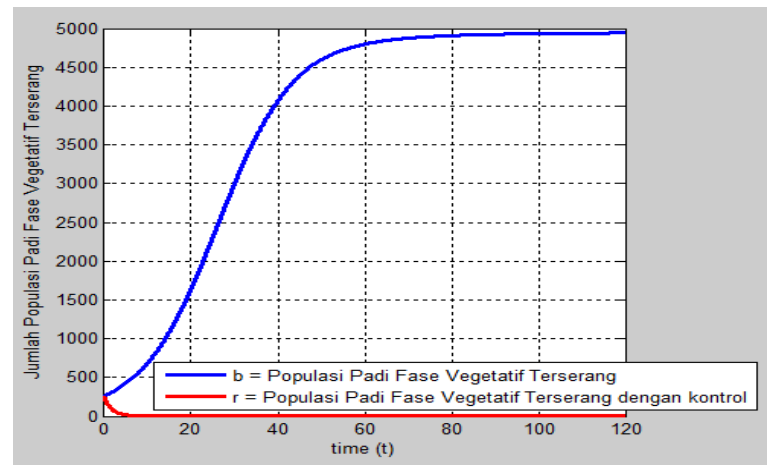

Gambar 4 : Kerusakan Populasi Tanaman Padi Fase Vegetatif Tanpa Kendali Dan Dengan Kendali

Gambar 4 menunjukkan perubahan pertumbuhan padi fase vegetatif $(\mathrm{Pv})$ terserang yang diberikan nilai awal 250 saat $t=0$, populasi ini terus meningkat hingga mencapai 4500 rumpun pada saat $t=48$ hari. Hal ini berbeda jika dilakukan pengendalian dimana populasi ini menurun hingga mencapai angka 0.0027 pada hari ke-8 yang mengindikasikan populasi pada fase vegetatif bebas dari serangan hama.

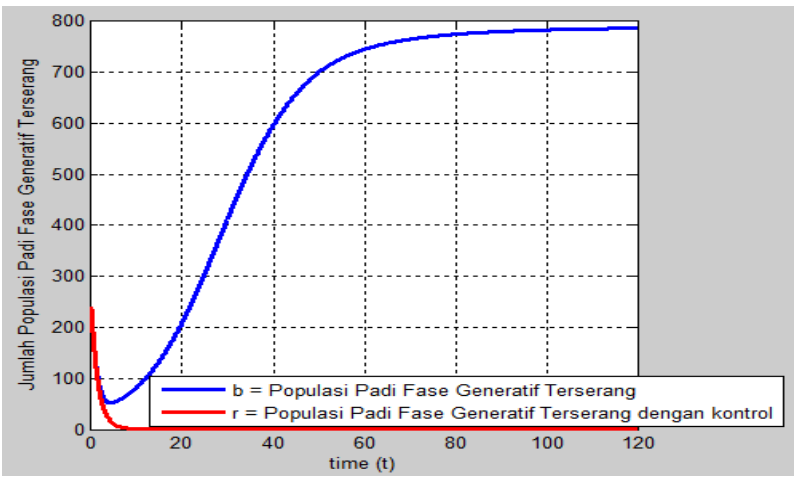

Gambar 5 : Kerusakan Populasi Tanaman Padi Fase Generatif Tanpa Kendali Dan Dengan Kendali

Gambar 5 menunjukkan kurva pertumbuhan populasi padi fase generatif terserang yang diberikan nilai awal $P g(0)=240$ rumpun untuk $t=0$. Populasi ini menurun hingga mencapai 78 rumpun pada saat $t(6)$, namun populasi ini akan kembali meningkat hingga mencapai 780 rumpun pada hari ke-100. Hal ini menunjukkan bahwa penurunan jumlah populasi terserang tanpa pengontrolan hanya sementara. Namun demikian, hal ini dapat ditekan dengan pengontrolan, dimana populasi ini akan menurun hingga mencapai 0.0038 rumpun pada waktu $t=100$ yang memberi arti bahwa populasi ini terbebas dari hama. 


\section{KESIMPULAN}

1. Dari hasil penelitian diperoleh desain kendali optimal dengan Indeks Performance $\min J=\int_{t_{0}}^{t_{f}}\left[\frac{1}{2}\left(u_{1}^{2}+u_{2}^{2}\right)-P v\right] d t$ dan kondisi satasioner $u_{1}^{*}=\lambda_{2} P v T$ untuk kendali hama tikus sawah dan $u_{2}^{*}=\lambda_{2} P v W$ untuk pengendalian WBC.

2. Hasil simulasi menunjukan bahwa penelitian ini hanya optimal pada pertumbuhan populasi tanaman padi, sementara untuk kedua hama belum optimal. Hal ini disebabkan desain kendali yang dibangun hanya untuk meminimumkan jumlah kerusakan populasi padi fase vegetatif.

\section{DAFTAR PUSTAKA}

[1] Anggraini S, Serangan Hama Wereng dan Kepik Pada Tanaman Padi Sawah Lebak Sumatra Selatan, 2014, Prosiding Seminar Nasional Lahan Suboptimal, Palembang.

[2] Badan Pusat Statistik, Produksi Tanaman Padi Seluruh Provinsi. 2011, Http://bps.tnmnpgn.go.id, diakses pada tanggal 09 Desember 2015.

[3] Baehaki, S.e, Standar Operasional Prosedur Pengendalian Wereng Coklat dan Virus Kerdil. 2011, Balai Besar Penelitian Tanaman Padi, Sukamandi.

[4] Harahap, i.S., Thahjono, B, Pengendalian Hama Dan Penyakit Padi , 1988, PT. Penebar Swadaya, Jakarta.

[5] Priyambodo, S, Pengendalian Hama tikus Terpadu, 1995, PT. Penebar Swadaya, Jakarta.

[6] Rismunandar, Hama Tanaman Pangan dan Pembasmiannya. 1993, Sinar Baru, Bandung.

[7] Solikhin dan Purnomo, Preferensi Tikus Sawah (Rattus-Rattus Argentiventer) dan Pengaruhnya Terhadap Pola Kerusakan Padi Varietas Dodokan dan Cianjur, 2008, Vol. 8. No 1:23, J. HPT Tropika. ISSN 1411-7525. 